\title{
Synergistic Extraction Equilibrium of Lanthanide(III) Ions with Benzoylacetone and a Neutral Ligand in an Ionic Liquid
}

\author{
Mizuki HATAKEYAMA ${ }^{1}$, Yoshio NISHIYAMA ${ }^{1, *}$, Hirohisa NAGATANI ${ }^{1}$, \\ Hiroyuki OKAMURA ${ }^{2}$ and Hisanori IMURA ${ }^{1, *}$ \\ ${ }^{1}$ Division of Material Chemistry, Graduate School of Natural Science and Technology, Kanazawa University, \\ Kakuma, Kanazawa 920-1192, Japan; ${ }^{2}$ Advance Science Research Center, Japan Atomic Energy Agency \\ (JAEA), 2-4, Shirakawa, Tokai-mura, Ibaraki 319-1195, Japan
}

(Received December 28, 2017; Accepted February 11, 2018)

The synergistic extraction of trivalent lanthanide ions $(\operatorname{Ln}(\mathrm{III}))$ with benzoylacetone ( $\mathrm{Hba})$ and trioctyphosphine oxide (TOPO) in an ionic liquid (IL), 1-butyl-3-methyl-imidazolium bis(trifluoromethanesulfonyl)imide ([Bmim] $\left.\left[\mathrm{Tf}_{2} \mathrm{~N}\right]\right)$, has been investigated. The extractability of $\mathrm{Ln}(\mathrm{III})$ with Hba was significantly enhanced in the presence of TOPO. The composition and extraction constants of the extracted species for each Ln(III) in the presence or absence of TOPO were determined by 3-dimensional equilibrium analysis. It was found that all $\mathrm{Ln}(\mathrm{III})$ were extracted as cationic ternary complexes such as $\mathrm{Ln}(\mathrm{ba})_{2}(\mathrm{TOPO})_{2}{ }^{+}$or $\mathrm{Ln}(\mathrm{ba})(\mathrm{TOPO})_{4}{ }^{2+}$ with $\mathrm{Hba}$ and TOPO, while $\mathrm{Ln}(\mathrm{III})$ was extracted as a neutral or cationic species such as $\operatorname{Ln}(\mathrm{ba})_{3}$ or $\mathrm{Ln}(\mathrm{ba})_{2}{ }^{+}$with $\mathrm{Hba}$ alone. The formation constants of the cationic ternary complexes in the IL were calculated from the corresponding extraction constants obtained, indicating that $\mathrm{Lu}(\mathrm{ba})(\mathrm{TOPO})_{4}{ }^{2+}$ is the most stable complex in the IL. Separation efficiency between different $\mathrm{Ln}(\mathrm{III})$ was also discussed on the basis of the extraction constants. The result demonstrated that the Hba-TOPO$[\mathrm{Bmim}]\left[\mathrm{Tf}_{2} \mathrm{~N}\right]$ system presented here is superior in the separation between heavier $\operatorname{Ln}(\mathrm{III})$.

\section{Introduction}

Ionic liquids (ILs) have attracted much attentions as alternative extraction solvents to conventional organic solvents in solvent extraction [1]. ILs are classified into novel types of molten salts that are liquids at below $100^{\circ} \mathrm{C}$ [2]. They have unique properties such as low vapor pressure, low flammability, and moderate electric conductivity that are advantageous for a variety of synthetic, catalytic, electrochemical and analytical applications. In the field of solvent extraction, ILs of an ionic nature act as not only extraction solvents but also ion-exchangers that allow for the extraction of charged species into the IL phase. Jensen et al. reported that neodymium(III) and europium(III) were extracted as not only neutral species but also anionic species in a water-IL system with a $\beta$-diketone [3]. Due to the unique extraction behavior, the IL system has the potential to achieve separation among chemical species that are not separable with conventional organic solvent systems.

Trivalent lanthanide ions $(\operatorname{Ln}(\mathrm{III}))$ are difficult to be separated mutually due to their remarkable chemical similarity, e.g. ionic diameter, coordination number, hydrolysis behavior in solution, and hardness as Lewis acids. We investigated the synergistic extraction of $\operatorname{Ln}(\mathrm{III})$ with $\beta$-diketones and several neutral 
ligands in a water-IL system [4-6]. The synergistic enhancement of the extractability depends largely on the type of the neutral ligand, e.g. selective extraction of lighter $\operatorname{Ln}(\mathrm{III})$ was achieved with 18-crown-6 as a synergist [5] while heavier $\operatorname{Ln}(\mathrm{III})$ were extracted selectively with trioctyphosphine oxide (TOPO) as a synergist [6]. It was also found that the separation efficiency of $\operatorname{Ln}(\mathrm{III})$ varied with the acidity of the $\beta$ diketones using as the extractants, e.g. the separation factor between $\mathrm{Eu}(\mathrm{III})$ and $\mathrm{Lu}(\mathrm{III})$ in the synergistic extraction system using benzoylacetone ( $\mathrm{Hba}$ ) with a higher $\mathrm{p} K_{\mathrm{a}}$ is significantly larger than those with other $\beta$-diketones [6]. Although synergistic extraction of Ln(III) in ILs has been investigated by a variety of groups [7-10], comprehensive understanding of the unique extraction mechanism in ILs has not yet been achieved. For that purpose, it is quite important to identify the extracted species and determine their extraction constants because all types of neutral and charged complexes may be extracted into ILs.

In the present paper, the composition and extraction constants of $\operatorname{Ln}(\mathrm{III})$ species in the chelate extraction with Hba alone and the synergistic extraction with Hba and TOPO in an ionic liquid 1-butyl-3methyl-imidazolium bis(trifluoromethanesulfonyl)imide $\left([\mathrm{Bmim}]\left[\mathrm{Tf}_{2} \mathrm{~N}\right]\right)$ were determined by 3 -dimensional (3D) equilibrium analysis. The formation constants of the adducts or ternary complexes of $\mathrm{Ln}$ (III) with $\mathrm{ba}^{-}$ and TOPO in IL as well as the separation factors between $\mathrm{Ln}$ (III) were determined using the extraction constants obtained in order to characterize the IL extraction systems.

\section{Experimental}

\subsection{Reagents}

Hba (Wako, 99\% purity), acetylacetone (abbreviated as Hacac, SIGMA-ALDRICH, 98\% purity), dibenzoylmethane (abbreviated as Hdbm, Nakalai, guaranteed grade), and TOPO (SIGMA-ALDRICH, 98.5\% purity) were used without further purification. All other chemicals used were of analytical or guaranteed reagent-grade, and were used as received. $\left[\mathrm{Bmim}_{[}\right]\left[\mathrm{Tf}_{2} \mathrm{~N}\right]$ was synthesized and purified in the same manner as previously reported [11].

\subsection{Apparatus}

A high speed shaker (ASONE, ASCM-1) was used for the agitation of the aqueous and ionic liquid phase. A pH meter (HORIBA, F-71) equipped with a micro glass combined electrode (HORIBA, 9618-10D) was calibrated with standard $\mathrm{pH}$ buffer solutions. An inductively coupled plasma mass spectrometer (ICPMS, Seiko Instruments SPQ 9000) was used for the determination of $\operatorname{Ln}(\mathrm{III})$ in aqueous solutions. A MilliQ system (Millipore, Direct-Q3UV) was used for preparation of high purity water (18.2 M 2 ).

\subsection{Extraction procedure}

An aliquot $\left(0.7 \mathrm{~cm}^{3}\right)$ of an aqueous phase containing $(0.50-3.0) \times 10^{-5} \mathrm{~mol} \mathrm{dm}^{-3} \operatorname{Ln}(\mathrm{III}), 1.0 \times 10^{-1}$ $\mathrm{mol} \mathrm{dm}{ }^{-3} \mathrm{NaCl}$, and $1.0 \times 10^{-2} \mathrm{~mol} \mathrm{dm}^{-3} \mathrm{pH}$ buffer (sulfanilic acid, acetic acid, MES, and HEPES) and an aliquot $\left(0.7 \mathrm{~cm}^{3}\right)$ of an IL phase containing $(0.010-1.0) \times 10^{-1} \mathrm{~mol} \mathrm{dm}^{-3} \beta$-diketone and $(0.10-1.0) \times 10^{-2}$ mol dm ${ }^{-3}$ TOPO were shaken mechanically at $25{ }^{\circ} \mathrm{C}$. The shaking time was $1 \mathrm{~h}$ for $\mathrm{La}(\mathrm{III}), \mathrm{Nd}(\mathrm{III})$, and $\mathrm{Eu}(\mathrm{III})$ and $2 \mathrm{~h}$ for Dy(III) and $\mathrm{Lu}(\mathrm{III})$. After the two phases were separated by centrifugation, the $\mathrm{pH}$ in the aqueous phase was measured. The metal concentration in the aqueous and the IL phase (after back-extraction into an equal volume of $0.1 \mathrm{~mol} \mathrm{dm}{ }^{-3}$ hydrochloric acid solution by shaking for $2 \mathrm{~h}$ ) was determined by ICPMS. The extraction percentage $(\% E)$ and distribution ratio $(D)$ were calculated from the concentrations of $\mathrm{Ln}(\mathrm{III})$ in both phases. 
To determine the distribution constant of $\mathrm{Hba}$, an aliquot $\left(1.0 \mathrm{~cm}^{3}\right)$ of the IL phase containing $(0.10-$ $1.0) \times 10^{-2} \mathrm{~mol} \mathrm{dm}^{-3} \mathrm{Hba}$ and an aliquot $\left(5.0 \mathrm{~cm}^{3}\right)$ of the aqueous phase containing $1.0 \times 10^{-1} \mathrm{~mol} \mathrm{dm}^{-3} \mathrm{NaCl}$ and $5.0 \times 10^{-3} \mathrm{~mol} \mathrm{dm}^{-3} \mathrm{pH}$ buffers (monochloroacetic acid, sodium dihydrogenphosphate, CHES, and CAPS) were shaken mechanically for $1 \mathrm{~h}$ at $25^{\circ} \mathrm{C}$. The $\mathrm{pH}$ of the aqueous phase was adjusted to $1-12$ with $1.0 \times 10^{-1} \mathrm{~mol} \mathrm{dm}^{-3} \mathrm{HCl}$ and $1.0 \times 10^{-1} \mathrm{~mol} \mathrm{dm}^{-3} \mathrm{NaOH}$. After the two phases were separated by centrifugation, the $\mathrm{pH}$ value of the aqueous phase was measured and diluted 1.25 times with $1.0 \times 10^{-1} \mathrm{~mol}$ $\mathrm{dm}^{-3} \mathrm{HCl}$ and $1.0 \times 10^{-1} \mathrm{~mol} \mathrm{dm}^{-3} \mathrm{NaCl}$. Then the absorbance of the solution at $\mathrm{pH}<2$ was measured at 310 $\mathrm{nm}$. The concentration of $\mathrm{Hba}$ in the aqueous phase was determined from the absorbance measured and the molar absorption coefficient of Hba determined separately as $5.0 \times 10^{3} \mathrm{dm}^{3} \mathrm{~mol}^{-1} \mathrm{~cm}^{-1}$. The distribution ratio of Hba was calculated according to the following equation.

$$
D_{\mathrm{HA}}=\frac{c_{\mathrm{HA}} V_{\mathrm{IL}}-c_{\mathrm{aq}} V}{c_{\mathrm{aq}} V_{\mathrm{IL}}},
$$

where $c_{\mathrm{HA}}, c_{\mathrm{aq}}, V$, and $V_{\mathrm{IL}}$ are the initial concentration of $\mathrm{Hba}$, the total concentration of $\mathrm{Hba}$ in the aqueous phase, the volumes of the aqueous phase, and the volumes of the IL phase, respectively.

\section{Theoretical background for extraction equilibrium analysis}

As mentioned above, $\mathrm{Ln}(\mathrm{III})$ can be extracted as not only neutral species but also cationic and anionic species into the IL phase. To identify the extracted species, the experimental distribution ratio data was analyzed according to the following extraction equilibria. In the extraction with $\mathrm{Hba}$ alone, the extraction equilibria and the extraction constants are expressed as follows.

For neutral species,

$$
\begin{aligned}
& \mathrm{Ln}^{3+}+3 \mathrm{Hba}_{(\mathrm{IL})} \rightleftarrows \mathrm{Ln}(\mathrm{ba})_{3(\mathrm{IL})}+3 \mathrm{H}^{+} \\
& K_{\mathrm{ex}, 3}=\frac{\left[\mathrm{Ln}(\mathrm{ba})_{3}\right]_{\mathrm{IL}}\left[\mathrm{H}^{+}\right]^{3}}{\left[\mathrm{Ln}^{3+}\right][\mathrm{Hba}]_{\mathrm{IL}}^{3}} .
\end{aligned}
$$

For cationic species $(m<3)$,

$$
\begin{aligned}
& \mathrm{Ln}^{3+}+m \mathrm{Hba}_{(\mathrm{IL})}+(3-m) \mathrm{Bmim}_{(\mathrm{IL})}^{+} \rightleftarrows \mathrm{Ln}(\mathrm{ba})_{m(\mathrm{IL})}^{(3-m)+}+m \mathrm{H}^{+}+(3-m) \\
& K_{\mathrm{ex}, m}=\frac{\left[\mathrm{Ln}(\mathrm{ba})_{m}^{(3-m)+}\right]_{\mathrm{IL}}\left[\mathrm{H}^{+}\right]^{m}\left[\mathrm{Bmim}^{+}\right]^{(3-m)}}{\left[\mathrm{Ln}^{3+}\right][\mathrm{Hba}]_{\mathrm{IL}}^{m}\left[\mathrm{Bmim}^{+}\right]_{\mathrm{IL}}^{(3-m)}} .
\end{aligned}
$$

For anionic species $(m>3)$,

$$
\begin{aligned}
& \mathrm{Ln}^{3+}+m \mathrm{Hba}_{(\mathrm{IL})}+(m-3) \mathrm{Tf}_{2} \mathrm{~N}_{(\mathrm{IL})}^{-} \rightleftarrows \mathrm{Ln}(\mathrm{ba})_{m(\mathrm{IL})}^{(m-3)-}+m \mathrm{H}^{+}+(m-3) \mathrm{Tf}_{2} \mathrm{~N}^{-} \\
& K_{\mathrm{ex}, m}=\frac{\left[\mathrm{Ln}(\mathrm{ba})_{m}^{(m-3)-}\right]_{\mathrm{IL}}\left[\mathrm{H}^{+}\right]^{m}\left[\mathrm{Tf}_{2} \mathrm{~N}^{-}\right]^{(m-3)}}{\left[\mathrm{Ln}^{3+}\right][\mathrm{Hba}]_{\mathrm{IL}}^{m}\left[\mathrm{Tf}_{2} \mathrm{~N}^{-}\right]_{\mathrm{IL}}^{(m-3)}}
\end{aligned}
$$

where the subscript IL denotes the IL phase. Here, $\left[\mathrm{Bmim}^{+}\right],\left[\mathrm{Bmim}^{+}\right]_{\mathrm{IL}},\left[\mathrm{Tf}_{2} \mathrm{~N}^{-}\right]$, and $\left[\mathrm{Tf}_{2} \mathrm{~N}^{-}\right]_{\mathrm{IL}}$ can be 
regarded as a constant. Thus, the following apparent equilibrium constants were derived from Eqs. (5) and (7):

$$
\begin{aligned}
& K_{\mathrm{ex}, m}^{\prime}=\frac{K_{\mathrm{ex}, m}\left[\mathrm{Bmim}^{+}\right]_{\mathrm{IL}}^{(3-m)}}{\left[\mathrm{Bmim}^{+}\right]^{(3-m)}}=\frac{\left[\mathrm{Ln}(\mathrm{ba})_{m}^{(3-m)+}\right]_{\mathrm{IL}}\left[\mathrm{H}^{+}\right]^{m}}{\left[\mathrm{Ln}^{3+}\right][\mathrm{Hba}]_{\mathrm{IL}}^{m}}(m<3) \\
& K_{\mathrm{ex}, m}^{\prime}=\frac{K_{\mathrm{ex}, m}\left[\mathrm{Tf}_{2} \mathrm{~N}^{-}\right]_{\mathrm{IL}}^{(m-3)}}{\left[\mathrm{Tf}_{2} \mathrm{~N}^{-}\right]^{(m-3)}}=\frac{\left[\mathrm{Ln}(\mathrm{ba})_{m}^{(m-3)-}\right]_{\mathrm{IL}}\left[\mathrm{H}^{+}\right]^{m}}{\left[\mathrm{Ln}^{3+}\right][\mathrm{Hba}]_{\mathrm{IL}}^{m}}(m>3) .
\end{aligned}
$$

From Eqs. (3), (8), and (9), when the amount of Ln-ba complexes in the aqueous phase is negligible, the distribution ratio of $\operatorname{Ln}(\mathrm{III})$ between the two phases that was determined experimentally is expressed as follows.

$$
\begin{aligned}
D & =\frac{\sum_{m<3}\left[\operatorname{Ln}(\mathrm{ba})_{m}^{(3-m)+}\right]_{\mathrm{IL}}+\left[\operatorname{Ln}(\mathrm{ba})_{3}\right]_{\mathrm{IL}}+\sum_{m>3}\left[\operatorname{Ln}(\mathrm{ba})_{m}^{(m-3)-}\right]_{\mathrm{IL}}}{\left[\mathrm{Ln}^{3+}\right]} \\
& =\sum_{m<3} \frac{\left[\mathrm{ba}^{-}\right]^{m} K_{\mathrm{ex}, m}^{\prime} K_{\mathrm{D}, \mathrm{HA}}^{m}}{K_{\mathrm{a}}^{m}}+\frac{\left[\mathrm{ba}^{-}\right]^{3} K_{\mathrm{ex}, 3} K_{\mathrm{D}, \mathrm{HA}}^{3}}{K_{\mathrm{a}}^{3}}+\sum_{m>3} \frac{\left[\mathrm{ba}^{-}\right]^{m} K_{\mathrm{ex}, m}^{\prime} K_{\mathrm{D}, \mathrm{HA}}^{m}}{K_{\mathrm{a}}^{m}},
\end{aligned}
$$

where $\left[\mathrm{ba}^{-}\right], K_{\mathrm{D}, \mathrm{HA}}$, and $K_{\mathrm{a}}$ represent the concentration of $\mathrm{ba}^{-}$in the aqueous phase, the distribution constant of Hba between the two phases, and the acid dissociation constant of $\mathrm{Hba}$ in the aqueous phase, respectively. $K_{\mathrm{D}, \mathrm{HA}}$ and $K_{\mathrm{a}}$ are given by

$$
\begin{gathered}
K_{\mathrm{D}, \mathrm{HA}}=\frac{[\mathrm{Hba}]_{\mathrm{IL}}}{[\mathrm{Hba}]} \\
K_{\mathrm{a}}=\frac{\left[\mathrm{ba}^{-}\right]\left[\mathrm{H}^{+}\right]}{[\mathrm{Hba}]} .
\end{gathered}
$$

The concentration of $\mathrm{ba}^{-}$in the aqueous phase is calculated by the following equation:

$$
\left[\mathrm{ba}^{-}\right]=\frac{c_{\mathrm{HA}} K_{\mathrm{a}}}{\left(K_{\mathrm{D}, \mathrm{HA}}+1\right)\left[\mathrm{H}^{+}\right]+\left(K_{\mathrm{D}, \mathrm{A}}+1\right) K_{\mathrm{a}}},
$$

where $c_{\mathrm{HA}}$ is the initial concentration of $\mathrm{Hba}$ in the IL phase, and $K_{\mathrm{D}, \mathrm{A}}$ is the apparent distribution constant of $\mathrm{ba}^{-}$that is given by

$$
K_{\mathrm{D}, \mathrm{A}}=\frac{\left[\mathrm{ba}^{-}\right]_{\mathrm{IL}}}{\left[\mathrm{ba}^{-}\right]} .
$$

Actually, the ba ${ }^{-}$transfers between the aqueous and IL phases by ion exchange with $\mathrm{Tf}_{2} \mathrm{~N}^{-}$can affect $\left[\mathrm{Tf}_{2} \mathrm{~N}^{-}\right]$. However, under the present conditions where $\left[\mathrm{ba}^{-}\right]$(at most $1.6 \times 10^{-3} \mathrm{~mol} \mathrm{dm}^{-3}$ ) is much smaller than $\left[\mathrm{Tf}_{2} \mathrm{~N}^{-}\right]$ $\left(1.6 \times 10^{-2} \mathrm{~mol} \mathrm{dm}^{-3}[12]\right)$, ion exchange between $\mathrm{ba}^{-}$and $\mathrm{Tf}_{2} \mathrm{~N}^{-}$hardly affect $\left[\mathrm{Tf}_{2} \mathrm{~N}^{-}\right]$and thus $K_{\mathrm{D}, \mathrm{A}}$ can be regarded as a constant. Similarly, the extraction of $\mathrm{Ln}(\mathrm{III})$ with Hba and TOPO is expressed as follows. For neutral species,

$$
\begin{aligned}
& \mathrm{Ln}^{3+}+3 \mathrm{Hba}_{(\mathrm{IL})}+n \mathrm{TOPO}_{(\mathrm{IL})} \rightleftarrows \mathrm{Ln}(\mathrm{ba})_{3}(\mathrm{TOPO})_{n(\mathrm{IL})}+3 \mathrm{H}^{+} \\
& K_{\mathrm{ex}, \mathrm{s} 3 n}=\frac{\left[\mathrm{Ln}(\mathrm{ba})_{3}(\mathrm{TOPO})_{n}\right]_{\mathrm{IL}}\left[\mathrm{H}^{+}\right]^{3}}{\left[\mathrm{Ln}^{3+}\right][\mathrm{Hba}]_{\mathrm{IL}}^{3}[\mathrm{TOPO}]_{\mathrm{IL}}^{n}} .
\end{aligned}
$$

For cationic species $(m<3)$, 


$$
\begin{aligned}
& \mathrm{Ln}^{3+}+m \mathrm{Hba}_{(\mathrm{IL})}+n \mathrm{TOPO}_{(\mathrm{IL})}+(3-m) \mathrm{Bmim}_{(\mathrm{IL})}^{+} \\
& \rightleftarrows \mathrm{Ln}(\mathrm{ba})_{m}(\mathrm{TOPO})_{n(\mathrm{IL})}^{(3-m)+}+m \mathrm{H}^{+}+(3-m) \mathrm{Bmim}^{+} \\
& K_{\mathrm{ex}, \mathrm{s} m n}^{\prime}=\frac{\left[\mathrm{Ln}(\mathrm{ba})_{m}(\mathrm{TOPO})_{n}^{(3-m)+}\right]_{\mathrm{IL}}\left[\mathrm{H}^{+}\right]^{m}}{\left[\mathrm{Ln}^{3+}\right][\mathrm{Hba}]_{\mathrm{IL}}^{m}[\mathrm{TOPO}]_{\mathrm{IL}}^{n}}
\end{aligned}
$$

For anionic species $(m>3)$,

$$
\begin{aligned}
& \mathrm{Ln}^{3+}+m \mathrm{Hba}_{(\mathrm{IL})}+n \mathrm{TOPO}_{(\mathrm{IL})}+(m-3) \mathrm{Tf}_{2} \mathrm{~N}_{(\mathrm{IL})}^{-} \\
& \rightleftarrows \mathrm{Ln}(\mathrm{ba})_{m}(\mathrm{TOPO})_{n}^{(m-3)-}+m \mathrm{H}^{+}+(m-3) \mathrm{Tf}_{2} \mathrm{~N}^{-} \\
& K_{\mathrm{ex}, s m n}^{\prime}=\frac{\left[\mathrm{Ln}(\mathrm{ba})_{m}(\mathrm{TOPO})_{n}^{(m-3)-}\right]_{\mathrm{IL}}\left[\mathrm{H}^{+}\right]^{m}}{\left[\mathrm{Ln}^{3+}\right][\mathrm{Hba}]_{\mathrm{IL}}^{m}[\mathrm{TOPO}]_{\mathrm{IL}}^{n}} .
\end{aligned}
$$

The distribution ratio between both phases in the synergistic extraction is expressed as

$$
\begin{aligned}
D & =\frac{\sum_{m<3} \sum_{n}\left[\mathrm{Ln}(\mathrm{ba})_{m}(\mathrm{TOPO})_{n}^{(3-m)+}\right]_{\mathrm{IL}}+\sum_{n}\left[\mathrm{Ln}(\mathrm{ba})_{3}(\mathrm{TOPO})_{n}\right]_{\mathrm{IL}}+\sum_{m>3} \sum_{n}\left[\mathrm{Ln}(\mathrm{ba})_{m}(\mathrm{TOPO})_{n}^{(m-3)-}\right]_{\mathrm{IL}}}{\left[\mathrm{Ln}^{3+}\right]} \\
& =\sum_{m<3} \sum_{n} \frac{\left[\mathrm{ba}^{-}\right]^{m}[\mathrm{TOPO}]_{\mathrm{IL}}^{n} K_{\mathrm{ex}, s m n}^{\prime} K_{\mathrm{D}, \mathrm{HA}}^{m}}{K_{\mathrm{a}}^{m}}+\sum_{n} \frac{\left[\mathrm{ba}^{-}\right]^{3}[\mathrm{TOPO}]_{\mathrm{IL}}^{n} K_{\mathrm{ex}, s 3 n}^{\prime} K_{\mathrm{D}, \mathrm{HA}}^{3}}{K_{\mathrm{a}}^{3}} \\
& +\sum_{m>3} \sum_{n} \frac{\left[\mathrm{ba}^{-}\right]^{m}[\mathrm{TOPO}]_{\mathrm{IL}}^{n} K_{\mathrm{ex}, s m n}^{\prime} K_{\mathrm{D}, \mathrm{HA}}^{m}}{K_{\mathrm{a}}^{m}}
\end{aligned}
$$

\section{Results and Discussion}

\subsection{Extraction behavior of $\operatorname{Ln}($ III) with $\beta$-diketones and TOPO}

Figure 1(a) shows the extractability of $\mathrm{Ln}(\mathrm{III})$ with $\mathrm{Hba}$ in the presence or absence of TOPO in $[\mathrm{Bmim}]\left[\mathrm{Tf}_{2} \mathrm{~N}\right]$ as a function of $\mathrm{pH}$ in the aqueous phase. With Hba alone, the $\mathrm{Ln}(\mathrm{III})$ were barely extractable
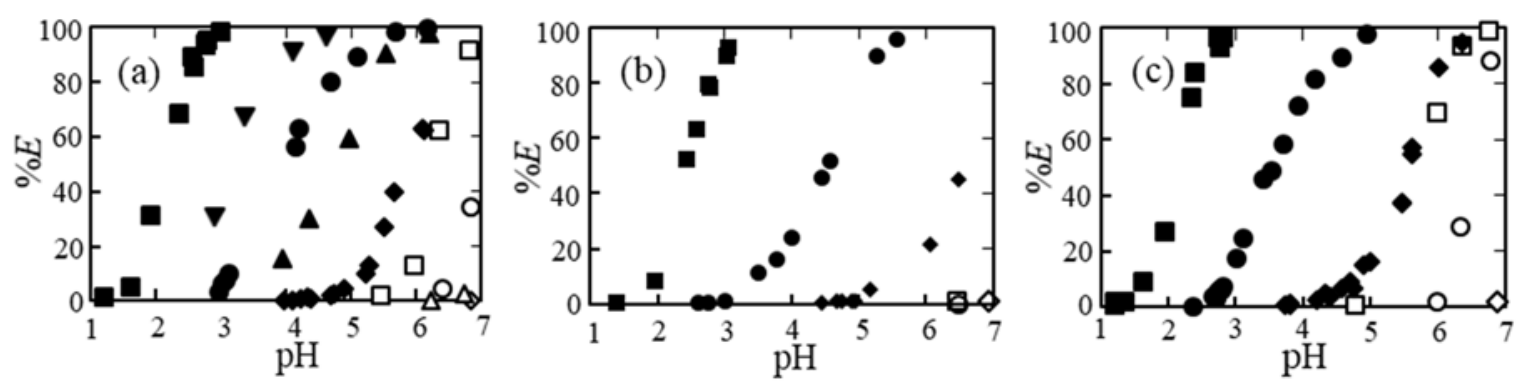

Figure 1. Extractability of $\operatorname{Ln}(\mathrm{III})$ with $\beta$-diketones in the presence or absence of TOPO in $[\mathrm{Bmim}]\left[\mathrm{Tf}_{2} \mathrm{~N}\right]$. Hba, Hacac, and Hdbm are used as $\beta$-diketones in panel (a), (b), and (c), respectively. The concentrations of $\beta$-diketones, TOPO, and $\operatorname{Ln}(\mathrm{III})$ are $1.0 \times 10^{-2} \mathrm{~mol} \mathrm{dm}^{-3}, 1.0$ $\times 10^{-2} \mathrm{~mol} \mathrm{dm}^{-3}$, and $5.0 \times 10^{-6}-3.0 \times 10^{-5} \mathrm{~mol} \mathrm{dm}^{-3}$, respectively. $\beta$-diketones alone system: $\diamond \mathrm{La}(\mathrm{III}), \triangle \mathrm{Nd}(\mathrm{III}), \bigcirc \mathrm{Eu}(\mathrm{III}), \square \mathrm{Lu}(\mathrm{III}) . \beta$-diketones-TOPO system ; $\bullet \mathrm{La}(\mathrm{III})$, $\mathrm{Nd}(\mathrm{III}), \mathrm{Eu}(\mathrm{III}), \boldsymbol{\nabla} \mathrm{Dy}(\mathrm{III}), \boldsymbol{\square} \mathrm{Lu}(\mathrm{III})$. 
or partially extracted at high $\mathrm{pH}$ into the IL phase. On the other hand, $\mathrm{Ln}(\mathrm{III})$ can be extracted at lower $\mathrm{pH}$ values with $\mathrm{Hba}$ and TOPO, indicating that the extraction of $\mathrm{Ln}(\mathrm{III})$, especially the heavier ones, was significantly enhanced due to the synergistic effect in this system. A similar synergistic effect was observed for the extraction with other $\beta$-diketones such as Hacac or Hdbm (Figure 1(b) and (c)).

\subsection{Determination of the distribution constant of $\mathrm{Hba}$ in the water-IL system}

The distribution of $\mathrm{Hba}$ between the aqueous and the IL phase is an important factor affecting the extraction efficiency of $\mathrm{Ln}(\mathrm{III})$. The distribution ratio $\left(D_{\mathrm{HA}}\right)$ of Hba between both phases was determined as a function of $\mathrm{pH}$ (shown in Figure 2). The $\mathrm{pH}$ dependence can be explained by the phase transfer of neutral $\mathrm{Hba}$ and anionic $\mathrm{ba}^{-}$, as reported for 2-thenoyltrifluoroacetone (Htta) [13]. At lower $\mathrm{pH}$ regions, $\log D_{\mathrm{HA}}$ was almost constant because neutral $\mathrm{Hba}$ is mainly formed and distributed between both phases. At a medium region of $\mathrm{pH}$, i.e. 8 to 11 , the $D_{\mathrm{HA}}$ value decreases with increasing of $\mathrm{pH}$ due to the formation of anionic $\mathrm{ba}^{-}$that is relatively stable in the aqueous phase compared with neutral $\mathrm{Hba}$. At higher $\mathrm{pH}$ values, the $D_{\mathrm{HA}}$ value was almost constant again because anionic $\mathrm{ba}^{-}$is mainly formed and distributed into the IL by an ionexchange mechanism. The experimentally determined $D_{\mathrm{HA}}$ value was expressed as follows.

$$
D_{\mathrm{HA}}=\frac{[\mathrm{Hba}]_{\mathrm{IL}}+\left[\mathrm{ba}^{-}\right]_{\mathrm{IL}}}{[\mathrm{Hba}]+\left[\mathrm{ba}^{-}\right]} \text {. }
$$

Using Eqs. (11), (12), and (14), Eq. (22) is rewritten as follows.

$$
D_{\mathrm{HA}}=\frac{K_{\mathrm{D}, \mathrm{HA}}+\left(K_{\mathrm{D}, \mathrm{A}} K_{\mathrm{a}} /\left[\mathrm{H}^{+}\right]\right)}{1+\left(K_{\mathrm{a}} /\left[\mathrm{H}^{+}\right]\right)} \text {. }
$$

By fitting the $\log D_{\mathrm{HA}}$ curve in Figure 2 by a nonlinear leastsquares method based on Eq. (23), the values of $\log K_{\mathrm{D}, \mathrm{HA}}$, $\log K_{\mathrm{D}, \mathrm{A}}$, and $\mathrm{p} K_{\mathrm{a}}$ were determined as $2.67 \pm 0.04,-0.84 \pm$ 0.13 , and $8.54 \pm 0.07$, respectively. The calculated results (the solid line in Figure 2) reproduced the experimental data well, and the value of $\mathrm{p} K_{\mathrm{a}}$ is consistent with the reported values (8.39 [14] and $8.96[15]$ at $I=0.1 \mathrm{~mol} \mathrm{dm}^{-3}$ and $25{ }^{\circ} \mathrm{C}$ ). The value of $\log K_{\mathrm{D}, \mathrm{HA}}$ in the present IL is smaller than that in benzene (3.02), indicating that Hba with a high hydrophobicity

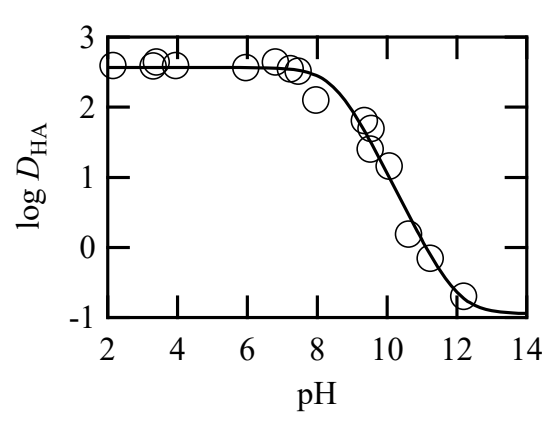

Figure 2. Distribution ratio of $\mathrm{Hba}$ as a function of $\mathrm{pH}$ in the aqueous phase. Initial concentration of $\mathrm{Hba}$ is $1.0 \times 10^{-3}-1.0 \times 10^{-2} \mathrm{~mol} \mathrm{dm}^{-3}$. The solid line shows the calculated values. has a higher affinity for benzene than for the IL.

\subsection{Determination of extraction constants for $\mathrm{Ln}$ (III) extraction with Hba alone}

To evaluate the extracted species for the extraction of $\operatorname{Ln}(\mathrm{III})$ with $\mathrm{Hba}$ alone, the distribution ratio was determined at various $\mathrm{pH}$ values in the aqueous phase and Hba concentration in the IL phase. In Figure 3 , the logarithmic distribution ratio was plotted as a function of the logarithmic concentration of ba $^{-}$that was calculated using Eq. (13). Among the Ln(III) investigated here, the slopes of the plots vary from two to three according to $\left[\mathrm{ba}^{-}\right]$, indicating that $\mathrm{Ln}(\mathrm{III})$ was extracted as $\operatorname{Ln}(\mathrm{ba})_{2}^{+}$at lower $\left[\mathrm{ba}^{-}\right]$and as $\operatorname{Ln}(\mathrm{ba})_{3}$ at higher $\left[\mathrm{ba}^{-}\right]$. Therefore, Eq. (10) is rewritten as follows.

$$
D=\frac{\left[\mathrm{ba}^{-}\right]^{2} K_{\mathrm{ex}, 2}^{\prime} K_{\mathrm{D}, \mathrm{HA}}^{2}}{K_{\mathrm{a}}^{2}}+\frac{\left[\mathrm{ba}^{-}\right]^{3} K_{\mathrm{ex}, 3} K_{\mathrm{D}, \mathrm{HA}}^{3}}{K_{\mathrm{a}}^{3}} .
$$


The extraction constants $K_{\mathrm{ex}, 2}^{\prime}$ and $K_{\mathrm{ex}, 3}$ for each $\mathrm{Ln}$ (III) were determined by fitting the $\log D-\log \left[\mathrm{ba}^{-}\right]$plots using Eq. (24) (shown in Table 1). As shown in Table 1, the values of $K_{\mathrm{ex}, 2}^{\prime}$ and $K_{\mathrm{ex}, 3}$ increase with an increase in the atomic number of the $\operatorname{Ln}(\mathrm{III})$. This tendency was also reported for most Ln(III) extractions [16], and can be interpreted from the electrostatic interactions between $\operatorname{Ln}(\mathrm{III})$ and $\mathrm{ba}^{-}$because basic ligands have stronger electrostatic interactions with heavier $\operatorname{Ln}(\mathrm{III})$ with smaller ionic radius. The values of $K_{\mathrm{ex}, 3}$ for $\mathrm{La}(\mathrm{III}), \mathrm{Eu}(\mathrm{III})$, and $\mathrm{Lu}(\mathrm{III})$ in IL are higher than those reported in benzene [17]. The extraction constant $K_{\mathrm{ex}, 3}$ is related to the distribution constant $\left(K_{\mathrm{D}, \mathrm{M} 3}\right)$ of the neutral chelate $\mathrm{Ln}(\mathrm{ba})_{3}$ between both phase as follows.

$$
K_{\mathrm{D}, \mathrm{M} 3} \beta_{3}=\frac{K_{\mathrm{ex}, 3} K_{\mathrm{D}, \mathrm{HA}}^{3}}{K_{\mathrm{a}}^{3}} .
$$

Here $\beta_{3}$ is the formation constant of $\operatorname{Ln}(\mathrm{ba})_{3}$ in the aqueous phase and thus independent of the extraction solvent. The values of $K_{\mathrm{D}, \mathrm{M} 3} \beta_{3}$, which were obtained with Eq. (25), were higher in the IL than those in benzene (shown in Table 1) in

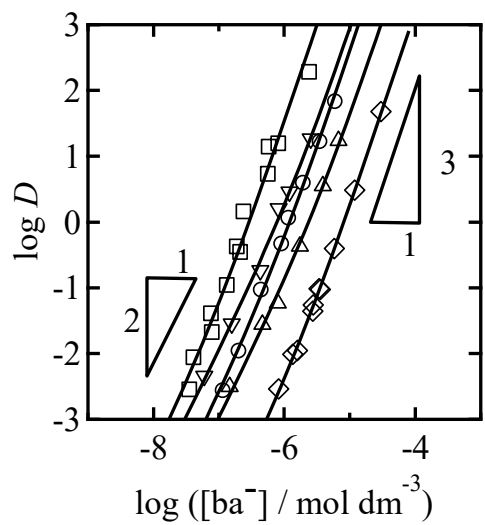

Figure 3. Distribution ratio of $\mathrm{Ln}(\mathrm{III})$ as a function of the $\mathrm{ba}^{-}$concentration in the aqueous phase. The solid line shows the calculated values. $1.0 \times$ $10^{-2}-3.0 \times 10^{-1} \mathrm{~mol} \mathrm{dm}^{-3} \mathrm{Hba}, 1.0$ $\times 10^{-5}-3.0 \times 10^{-5} \mathrm{~mol} \mathrm{dm}^{-3} \mathrm{Ln}(\mathrm{III})$. $\mathrm{pH} 4.4$ - 7.1. $\diamond \mathrm{La}(\mathrm{III}), \triangle$ $\mathrm{Nd}(\mathrm{III}), \quad \bigcirc \quad \mathrm{Eu}(\mathrm{III}), \quad \nabla \quad \mathrm{Dy}(\mathrm{III})$, $\mathrm{Lu}(\mathrm{III})$. spite of a lower $K_{\mathrm{D}, \mathrm{HA}}$ value in IL than in benzene $\left(K_{\mathrm{D}, \mathrm{HA}}(\mathrm{IL})<K_{\mathrm{D}, \mathrm{HA}}(\right.$ benzene $\left.)\right)$, indicating that the $\operatorname{Ln}(\mathrm{ba})_{3}$ chelates have higher affinities for IL that is more polar than benzene (e.g. $\mathcal{E}_{\mathrm{r}}=14.0$ for $[\mathrm{Bmim}]\left[\mathrm{Tf}_{2} \mathrm{~N}\right][18]$ and 2.27 for benzene [19]) and has the donating property of $\mathrm{Tf}_{2} \mathrm{~N}^{-}[20]$.

Table 1. Extraction constants of $\mathrm{Ln}(\mathrm{III})$ in the $\mathrm{Hba}-[\mathrm{Bmim}]\left[\mathrm{Tf}_{2} \mathrm{~N}\right]$ system at $25^{\circ} \mathrm{C}$.

\begin{tabular}{cccccc}
\hline \multirow{2}{*}{$\operatorname{Ln}(\mathrm{III})$} & \multicolumn{3}{c}{$[\mathrm{Bmim}]\left[\mathrm{Tf}_{2} \mathrm{~N}\right]$} & \multicolumn{2}{c}{ Benzene $^{\mathrm{a}}$} \\
\cline { 2 - 6 } & $\log K_{\mathrm{ex}, 2}^{\prime}$ & $\log K_{\mathrm{ex}, 3}$ & $\log K_{\mathrm{D}, \mathrm{M} 3} \beta_{3}$ & $\log K_{\mathrm{ex}, 3}$ & $\log K_{\mathrm{D}, \mathrm{M} 3} \beta_{3}$ \\
\hline $\mathrm{La}(\mathrm{III})$ & $-12.65 \pm 0.05$ & $-18.03 \pm 0.03$ & 15.63 & -20.46 & 14.70 \\
$\mathrm{Nd}(\mathrm{III})$ & $-11.11 \pm 0.08$ & $-16.69 \pm 0.14$ & 16.97 & - & - \\
$\mathrm{Eu}(\mathrm{III})$ & $-10.85 \pm 0.05$ & $-15.61 \pm 0.06$ & 18.05 & -18.90 & 16.26 \\
$\mathrm{Dy}(\mathrm{III})$ & $-10.08 \pm 0.08$ & $-15.35 \pm 0.15$ & 18.31 & - & - \\
$\mathrm{Lu}(\mathrm{III})$ & $-9.68 \pm 0.21$ & $-13.62 \pm 0.13$ & 20.04 & -15.21 & 19.95 \\
\hline
\end{tabular}

a : Ref. 17

\subsection{Determination of extraction constants for Ln(III) extraction with Hba and TOPO}

The distribution ratio for $\mathrm{Ln}(\mathrm{III})$ in the synergistic extraction was determined at varying $\mathrm{pH}$ and concentrations of $\mathrm{Hba}$ and TOPO. The 3D plot of $\log D$ for $\mathrm{Eu}(\mathrm{III})$ as a function of $\log \left[\mathrm{ba}^{-}\right]$and $\log [\mathrm{TOPO}]_{\mathrm{IL}}$ is shown in Figure 4, where two types of 2D plots, the $\log D-\log \left[\mathrm{ba}^{-}\right]$plot at fixed $\log [\mathrm{TOPO}]_{\mathrm{IL}}$ and the $\log D-\log [\text { TOPO }]_{\mathrm{IL}}$ plot at fixed $\log \left[\mathrm{ba}^{-}\right]$, are also shown. From the slope of the $\log D-\log \left[\mathrm{ba}^{-}\right]$plots, 
one or two ba $\mathrm{b}^{-}$ions were found to coordinate to Eu(III). Similarly, two to four TOPO molecules were found to be coordinated to $\mathrm{Eu}(\mathrm{III})$. Similar trends were observed in the $\log D$ plots for other $\mathrm{Ln}$ (III). Given that the coordination number of the $\mathrm{Ln}(\mathrm{III})$ is eight or nine, $\mathrm{Ln}(\mathrm{ba})(\mathrm{TOPO})_{2}^{2+}, \mathrm{Ln}(\mathrm{ba})(\mathrm{TOPO})_{3}^{2+}, \mathrm{Ln}(\mathrm{ba})(\mathrm{TOPO})_{4}^{2+}$, $\mathrm{Ln}(\mathrm{ba})_{2}(\mathrm{TOPO})_{2}^{+}, \mathrm{Ln}(\mathrm{ba})_{2}(\mathrm{TOPO})_{3}^{+}$and $\mathrm{Ln}(\mathrm{ba})_{2}(\mathrm{TOPO})_{4}^{+}$can be considered as the extracted species with $\mathrm{Hba}$ as a bidentate ligand and with TOPO as a unidentate ligand. According to Eq. (21), the extraction constants for the respective extracted species were determined by fitting the 3D plot of $\log D$ by a nonlinear least-squares method. Reliable fits were achieved by limiting the extracted species to $\operatorname{Ln}(\mathrm{ba})(\mathrm{TOPO})_{4}^{2+}$ and $\mathrm{Ln}(\mathrm{ba})_{2}(\mathrm{TOPO})_{2}^{+}$for $\mathrm{Ln}(\mathrm{III})$ except for $\mathrm{Lu}(\mathrm{III})$, and to only $\mathrm{Ln}(\mathrm{ba})(\mathrm{TOPO})_{4}^{2+}$ for $\mathrm{Lu}(\mathrm{III})$. As shown in Figure 4, the calculation using the extraction constants, i.e. solid curves, reproduced the experimental data. This fitting result indicates that only cationic ternary complexes were extracted in the synergistic extraction with $\mathrm{Hba}$ and TOPO, in contrast to the extraction with $\mathrm{Hba}$ alone where neutral and cationic species were extracted.
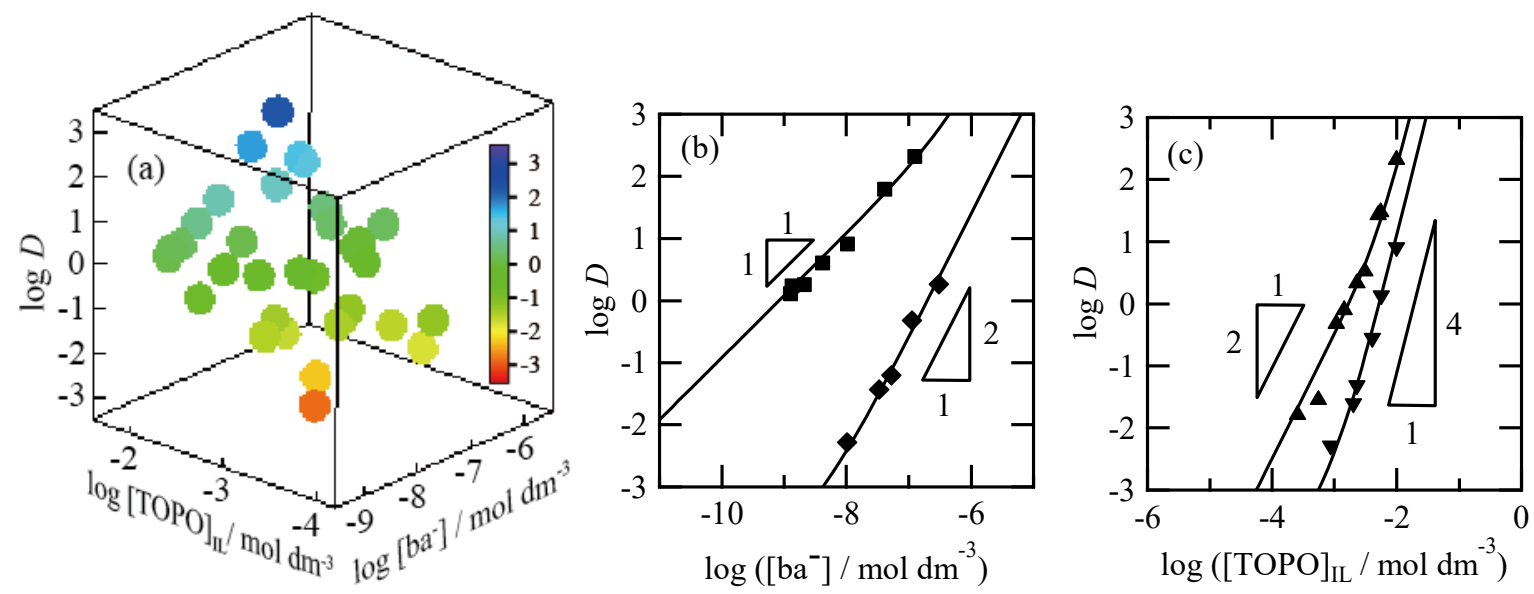

Figure 4. Distribution ratio $(D)$ of $\mathrm{Eu}(\mathrm{III})$ as a function of the concentration of $\mathrm{ba}^{-}$in the aqueous phase $\left(\left[\mathrm{ba}^{-}\right]\right)$and/or that of TOPO in the IL phase ([TOPO $\left.]_{\mathrm{IL}}\right)$. Panels (a), (b), (c) represent a 3D plot of $\log D$ against $\log \left[\mathrm{ba}^{-}\right]$and $\log [\mathrm{TOPO}]_{\mathrm{IL}}$, a $2 \mathrm{D}$ plot of $\log D$ against $\log \left[\mathrm{ba}^{-}\right]$, and a 2D plot of $\log D$ against $\log [\mathrm{TOPO}]_{\mathrm{IL}}$, respectively. Solid symbols show the experimental values $(\diamond \log$ $\left.[\mathrm{TOPO}]_{\mathrm{IL}}=-2.99, \boldsymbol{\square} \log [\mathrm{TOPO}]_{\mathrm{IL}}=-2.00, \boldsymbol{\nabla} \log \left[\mathrm{ba}^{-}\right]=-7.98, \boldsymbol{\Delta} \log \left[\mathrm{ba}^{-}\right]=-6.93\right)$. Curves in panels (b) and (c) show calculated results. $1.0 \times 10^{-2}-3.0 \times 10^{-2} \mathrm{~mol} \mathrm{dm}^{-3} \mathrm{Hba}, 1.0 \times 10^{-3}-1.0$ $\times 10^{-2} \mathrm{~mol} \mathrm{dm}^{-3}$ TOPO, $5.0 \times 10^{-5}-3.0 \times 10^{-5} \mathrm{~mol} \mathrm{dm}^{-3} \mathrm{Eu}(\mathrm{III}) . \mathrm{pH} 4.2-6.2$.

Synergistic extraction proceeds via the adduct formation of $\operatorname{Ln}(\mathrm{III})$ benzoylacetonate with TOPO in the IL phase. The following complexation equilibrium exists between $\operatorname{Ln}(\mathrm{ba})_{m}(\mathrm{TOPO})_{n}^{(3-m)+}$ that is extracted synergistically and $\operatorname{Ln}(\mathrm{ba})_{m^{\prime}}^{\left(3-m^{\prime}\right)+}$ that is extracted with Hba alone.

$$
\mathrm{Ln}(\mathrm{ba})_{m^{\prime}(\mathrm{IL})}^{\left(3-m^{\prime}\right)+}+n \mathrm{TOPO}_{(\mathrm{IL})} \rightleftarrows \mathrm{Ln}(\mathrm{ba})_{m}(\mathrm{TOPO})_{n,(\mathrm{IL})}^{(3-m)+}+\left(m^{\prime}-m\right) \mathrm{ba}_{(\mathrm{IL})}^{-}
$$

The adduct formation constant can be defined as

$$
\beta_{m^{\prime}}^{m n}=\frac{\left[\mathrm{Ln}(\mathrm{ba})_{m}(\mathrm{TOPO})_{n}^{(3-m)+}\right]_{\mathrm{IL}}}{\left[\mathrm{Ln}(\mathrm{ba})_{m^{\prime}}^{(3-m)+}\right]_{\mathrm{IL}}[\mathrm{TOPO}]_{\mathrm{IL}}^{n}}=\frac{K_{\mathrm{ex}, s m n}^{\prime} K_{\mathrm{a}}^{\left(m^{\prime}-m\right)} K_{\mathrm{D}, \mathrm{A}}^{\left(m^{\prime}-m\right)}}{K_{\mathrm{ex}, m^{\prime}}^{\prime} K_{\mathrm{D}, \mathrm{HA}}^{\left(m^{\prime}-m\right)}} .
$$


The adduct formation constants $\beta_{2}^{22}, \beta_{3}^{22}, \beta_{2}^{14}$, and $\beta_{3}^{14}$ were determined for $\mathrm{Ln}(\mathrm{III})$ except for $\mathrm{Lu}(\mathrm{III})$, while only $\beta_{2}^{14}$ and $\beta_{3}^{14}$ were determined for $\mathrm{Lu}(\mathrm{III})$ (listed in Table 2). For adduct formation of the cationic chelate $\mathrm{Ln}(\mathrm{ba})_{2}{ }^{+}$with two TOPO molecules, the value of the formation constant $\beta_{2}^{22}$ is maximized for $\mathrm{Eu}(\mathrm{III})$, as shown in Figure 5. This tendency with respect to the $\mathrm{Ln}(\mathrm{III})$ series is different from that in conventional organic solvent systems where the adduct formation constant decreases monotonously as the atomic number increases [16]. Furthermore, the value of $\beta_{2}^{14}$ increases with an increase in the atomic number and is particularly large for Lu(III). This tendency indicates that the heavier $\mathrm{Ln}$ (III) prefer to form the dicationic ternary complex $\mathrm{Ln}(\mathrm{ba})(\mathrm{TOPO})_{4}^{2+}$. For both of the two adduct complexes presented here, $\mathrm{ba}^{-}$and TOPO occupy six coordination

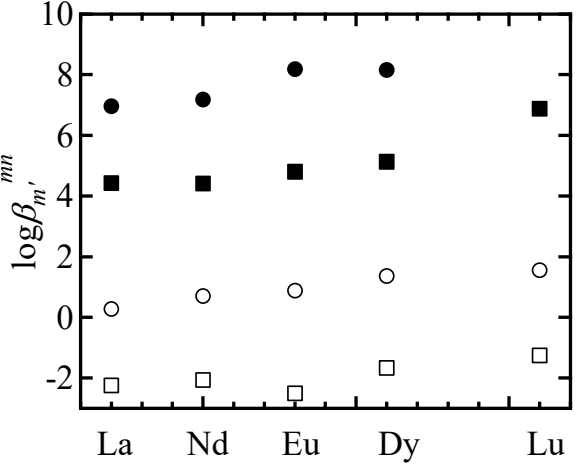

Figure 5. Variation of the adduct formation constants of $\operatorname{Ln}(\mathrm{III})$ in $[\mathrm{Bmim}]\left[\mathrm{Tf}_{2} \mathrm{~N}\right]$ across Ln series. $\bigcirc \log \beta_{3}^{22}, \square \log \beta_{3}^{14}, \bigcirc \log$ $\beta_{2}^{22}, \boldsymbol{\square} \log \beta_{2}^{14} .1 .0 \times 10^{-2}-3.0 \times 10^{-2} \mathrm{~mol}$ $\mathrm{dm}^{-3} \mathrm{Hba}, 1.0 \times 10^{-3}-1.0 \times 10^{-2} \mathrm{~mol} \mathrm{dm}^{-3}$ TOPO, $5.0 \times 10^{-6}-3.0 \times 10^{-5} \mathrm{~mol} \mathrm{dm}^{-3}$ Ln(III). pH $3.9-7.5$. sites of $\operatorname{Ln}(\mathrm{III})$, indicating that there is no significant difference in steric hindrance between the two complexes although a steric effect potentially has an influence on the adduct formation process for heavier Ln(III) with smaller ionic radius. Instead, preferential formation of the dicationic complex for heavier Ln(III) can be interpreted in terms of the hard-soft acid-base (HSAB) principle. The hard acid character of $\mathrm{Ln}(\mathrm{ba})^{2+}$ is greater than that of $\operatorname{Ln}(\mathrm{ba})_{2}{ }^{+}$and increases with the increase in the atomic number of $\operatorname{Ln}(\mathrm{III})$. Therefore, heavier Ln(III) have a higher affinity for TOPO than for $\mathrm{ba}^{-}$and tends to form the dicationic ternary complex that is coordinated with hydrophobic TOPO molecules instead of $\mathrm{ba}^{-}$in the IL.

The present equilibrium analysis also indicates that the coordination sites of $\mathrm{Ln}(\mathrm{III})$ for the extracted species are not fully occupied by $\mathrm{ba}^{-}$and TOPO, i.e. other molecules such as water or solvent ions are also coordinated. For the IL extraction system, it has been discussed whether the metal ions in the extracted species are hydrated or not, because ILs are capable of containing a significant amount of water molecules $\left(>1 \mathrm{~mol} \mathrm{dm}^{-3}\right.$ ) and the extractability is reduced by hydration. Luminescence lifetime measurements have been applied to estimate the number of water molecules coordinated to Eu(III). We previously demonstrated that $\mathrm{Eu}(\mathrm{III})$-tta chelates extracted into the IL phase are dehydrated [20]. At present, we are trying to apply this method for the present extraction system and the results will be reported in the near future.

Table 2. Extraction constants of $\mathrm{Ln}(\mathrm{III})$ in the Hba-TOPO-[Bmim] $\left[\mathrm{Tf}_{2} \mathrm{~N}\right]$ system and adduct formation constants of $\mathrm{Ln}(\mathrm{III})-\mathrm{Hba}-\mathrm{TOPO}$ in $[\mathrm{Bmim}]\left[\mathrm{Tf}_{2} \mathrm{~N}\right]$ at $25^{\circ} \mathrm{C}$

\begin{tabular}{ccccccc}
\hline $\mathrm{Ln}(\mathrm{III})$ & $\log K_{\text {ex,s22 }}^{\prime}$ & $\log K_{\text {ex,s14 }}^{\prime}$ & $\log \beta_{2}^{22}$ & $\log \beta_{3}^{22}$ & $\log \beta_{2}^{14}$ & $\log \beta_{3}^{14}$ \\
\hline $\mathrm{La}(\mathrm{III})$ & $-5.69 \pm 0.07$ & $3.85 \pm 0.05$ & $6.96 \pm 0.09$ & $0.28 \pm 0.08$ & $4.43 \pm 0.08$ & $-2.24 \pm 0.07$ \\
$\mathrm{Nd}(\mathrm{III})$ & $-3.93 \pm 0.05$ & $5.37 \pm 0.05$ & $7.18 \pm 0.10$ & $0.70 \pm 0.15$ & $4.42 \pm 0.10$ & $-2.07 \pm 0.15$ \\
$\mathrm{Eu}(\mathrm{III})$ & $-2.66 \pm 0.06$ & $6.01 \pm 0.06$ & $8.19 \pm 0.10$ & $0.88 \pm 0.09$ & $4.79 \pm 0.10$ & $-2.50 \pm 0.10$ \\
$\mathrm{Dy}(\mathrm{III})$ & $-1.93 \pm 0.14$ & $7.11 \pm 0.17$ & $8.15 \pm 0.10$ & $1.36 \pm 0.16$ & $5.12 \pm 0.12$ & $-1.67 \pm 0.17$ \\
$\mathrm{Lu}(\mathrm{III})$ & - & $9.26 \pm 0.05$ & - & - & $6.87 \pm 0.22$ & $-1.25 \pm 0.14$ \\
\hline
\end{tabular}




\subsection{Separation between lanthanide ions using synergistic extraction system}

The separation efficiency between different $\mathrm{Ln}$ (III) was examined in terms of separation factors that were calculated from the extraction constants determined above. The separation factor $\left(\alpha_{\mathrm{Ln}(\mathrm{III}) / \mathrm{Ln}(\mathrm{III})^{\prime}}\right)$ between $\mathrm{Ln}(\mathrm{III})$ and $\operatorname{Ln}(\mathrm{III})^{\prime}$ is defined as

$$
\begin{aligned}
\alpha_{\mathrm{Ln}(\mathrm{III}) \mathrm{Ln}(\mathrm{III})^{\prime}}= & \frac{D_{\mathrm{Ln}(\mathrm{III})}}{D_{\mathrm{Ln}(\mathrm{III})^{\prime}}} \\
= & \frac{\frac{\left[\mathrm{ba}^{-}\right][\mathrm{TOPO}]_{\mathrm{IL}}^{4} K_{\mathrm{ex}, \mathrm{S1} 4(\mathrm{Ln}(\mathrm{III}))}^{\prime} K_{\mathrm{D}, \mathrm{HA}}}{K_{\mathrm{a}}}+\frac{\left[\mathrm{ba}^{-}\right]^{2}[\mathrm{TOPO}]_{\mathrm{IL}}^{2} K_{\mathrm{ex}, \mathrm{s} 22(\mathrm{Ln}(\mathrm{III}))}^{\prime} K_{\mathrm{D}, \mathrm{HA}}^{2}}{\left.K_{\mathrm{a}}^{2}\right][\mathrm{TOPO}]_{\mathrm{IL}}^{4} K_{\mathrm{ex}, \mathrm{s} 14\left(\mathrm{Ln}(\mathrm{III})^{\prime}\right)}^{\prime} K_{\mathrm{D}, \mathrm{HA}}}}{K_{\mathrm{a}}}+\frac{\left[\mathrm{ba}^{-}\right]^{2}[\mathrm{TOPO}]_{\mathrm{IL}}^{2} K_{\mathrm{ex}, \mathrm{s} 22\left(\mathrm{Ln}(\mathrm{III})^{\prime}\right)}^{\prime} K_{\mathrm{D}, \mathrm{HA}}^{2}}{K_{\mathrm{a}}^{2}} .
\end{aligned}
$$

The 3D plots of $\log \alpha_{\mathrm{Eu}(\mathrm{III}) / \mathrm{La}(\mathrm{III})}$ and $\log \alpha_{\mathrm{Lu}(\mathrm{III}) / \mathrm{Eu}(\mathrm{III})}$ as functions of $\log \left[\mathrm{ba}^{-}\right]$and $\log [\mathrm{TOPO}]_{\mathrm{IL}}$ are shown in Figure 6. The separation factor between $\mathrm{Eu}(\mathrm{III})$ and $\mathrm{La}(\mathrm{III})$ is reduced slightly with an increase in [TOPO $]_{\mathrm{IL}}$. On the other hand, the separation factor between $\mathrm{Lu}(\mathrm{III})$ and $\mathrm{Eu}(\mathrm{III})$ varies significantly with both $\left.\mathrm{ba}^{-}\right]$and [TOPO $]_{\mathrm{IL}}$, and a value of $\alpha_{\mathrm{Lu}(\mathrm{IIII} / \mathrm{Eu}(\mathrm{III})}$ greater than $10^{3}$ is achieved at lower $\left[\mathrm{ba}^{-}\right]$and at higher [TOPO $]_{\mathrm{IL}}$. Variation of $\alpha_{\mathrm{Lu}(\mathrm{III}) / \mathrm{Eu}(\mathrm{III})}$ according to [ba- $]$ and [TOPO $]_{\mathrm{IL}}$ is ascribed to the difference in the composition of predominant adduct species: both monocationic and dicationic complexes are extracted competitively for $\mathrm{Eu}(\mathrm{III})$, whereas only a dicationic complex is extracted for $\mathrm{Lu}(\mathrm{III})$. In the extraction system using $\beta$-diketones in conventional organic solvents, separation between the heavier $\operatorname{Ln}(\mathrm{III})$ is poorer than that between lighter $\mathrm{Ln}(\mathrm{III})$ [15]. The IL synergistic extraction system presented here is capable of the extraction of various charged adduct complexes, which results in large synergistic effects and superior separation efficiency for the heavier $\operatorname{Ln}(\mathrm{III})$.
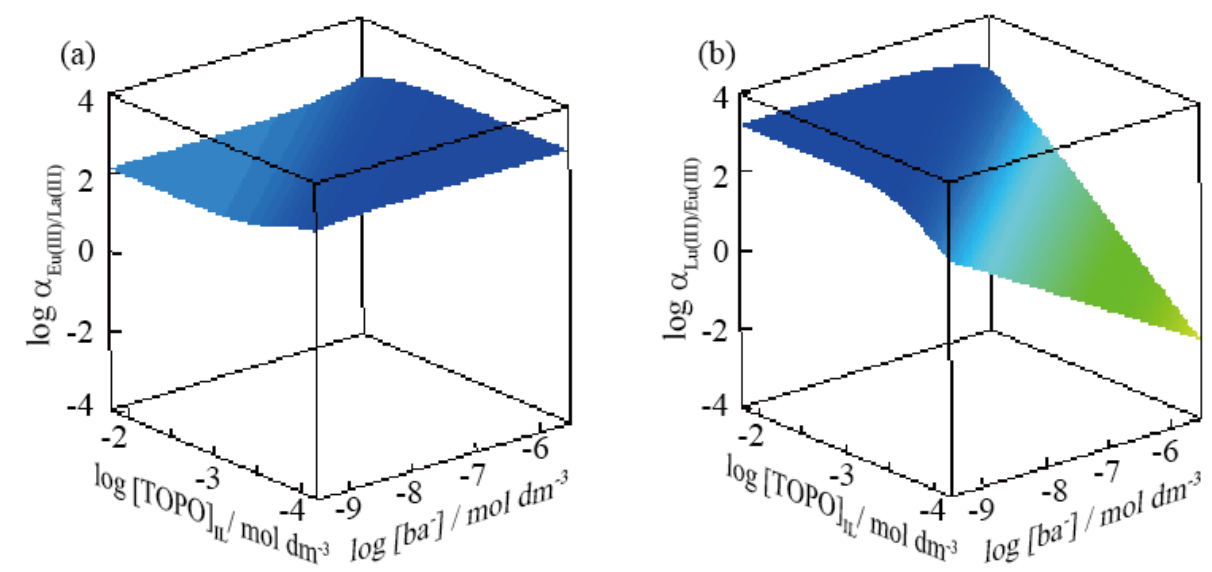

Figure 6. Separation factors (a) between $\mathrm{Eu}(\mathrm{III})$ and $\mathrm{La}(\mathrm{III})$ and (b) between $\mathrm{Lu}(\mathrm{III})$ and $\mathrm{Eu}(\mathrm{III})$, calculated from the determined extraction constants.

\section{Conclusion}

The synergistic extraction equilibrium of $\mathrm{Ln}(\mathrm{III})$ with $\mathrm{Hba}$ and $\mathrm{TOPO}$ in $[\mathrm{Bmim}]\left[\mathrm{Tf}_{2} \mathrm{~N}\right]$ was investigated, and the extracted species and their extraction constants were determined by the 3D equilibrium 
analysis. In the presence of TOPO, cationic adduct complexes such as $\mathrm{Ln}(\mathrm{ba})(\mathrm{TOPO})_{4}^{2+}$ and $\mathrm{Ln}(\mathrm{ba})_{2}(\mathrm{TOPO})_{2}^{+}$are found to be formed in the IL phase, in contrast to the extraction with Hba alone where neutral and cationic species are extracted. The formation constant for each adduct complex shows different trends among the $\mathrm{Ln}(\mathrm{III})$ series. The separation factors calculated from the determined extraction constants indicate that the present synergistic extraction system is capable of the selective extraction of the heavier $\operatorname{Ln}(\mathrm{III})$.

\section{Acknowledgement}

This study was supported by JSPS KAKENHI Grant Nos. 25288064 and 17K17757.

\section{References}

1) S. Dai, Y. H. Ju, C. E. Barnes, J. Chem. Soc., Dalton Trans. 1201-1202 (1999).

2) T. Welton, Chem. Rev., 99, 2071-2084 (1999).

3) M. P. Jensen, B. J. Neuefeind, S. Skanthakumar, L. Soderholm, J. Am. Chem. Soc., 125, 15466-15473 (2003)

4) N. Hirayama, H. Okamura, K. Kidani, H. Imura, Anal. Sci, 24, 697-699 (2008).

5) H. Okamura, N. Hirayama, K. Morita, K. Shimojo, H. Naganawa, H. Imura, Anal. Sci, 26, 607-611 (2010).

6) H. Okamura, H. Takagi, T. Isomura, K. Morita, H. Nagatani, H. Imura, Anal. Sci, 30, 323-325 (2014).

7) X. Sun, Y. Ji, F. Hu, J. Chen, D. Li, Talanta, 81, 1877-1883 (2010)

8) A. N. Turanov, V. K. Karandashev, V. E. Baulin, Solvent Extr. Ion Exch., 30, 244-261 (2012).

9) Z. Zhao, Y. Baba, F. Kubota, N. Kamiya, M. Goto, J. Chem. Eng. Jpn., 47, 656-662 (2014).

10) M. Atanassova, V. Kurteva, Sep. Purif Technol., 183, 226-236 (2017).

11) P. Bonhoôte, A. P. Dias, N. Papageorgiou, K. Kalyanasundaram, M. Grätzel, Inorg. Chem., 35, 1168-1178 (1996).

12) S. Katsuta, K. Nakamura, Y. Kudo, Y. Takeda, J. Phys. Chem. B, 116, 852-859 (2011)

13) K. Kidani, H. Imura, Talanta, 83, 299-304 (2010).

14) T. Sekine, Y. Hasegawa, N. Ihara, J. Inorg. Nucl. Chem., 35, 3968-3970 (1973).

15) A. P. Zozulya, N. N. Mezentseva, V. M. Peshkova, Y. Yuriev, Zh. Anal. Khim., 14, 17(1959).

16) T. Shigematsu, M. Tabushi, M. Matsui, T. Honjyo, Bull. Chem. Soc. Jpn., 40, 2807-2812 (1967).

17) J. Stay, Zh. Neorg. Khim., 4, 2412 (1959).

18) M. Huang, Y. Jiang, P. Sasisanker, G. Driver, H. Weingärtner, J. Chem. Eng. Data., 56, 1494-1499 (2011).

19) W. M. Haynes (ed.), CRC Handbook of Chemistry and Physics. 97st Edition, CRC Press, Boca Raton, 2010, p. 2229.

20) H. Okamura, N. Aoyagi, K. Shimojo, H. Naganawa, H. Imura, RSC Adv., 7, 7610-7618 (2017). 